"This is the peer reviewed version of the following article: [European Journal Of Inorganic Chemistry, 2013, 2013 (29), pp. 5133 - 5137], which has been published in final form at [http://dx.doi.org/10.1002/ejic.201300650]. This article may be used for non-commercial purposes in accordance with Wiley Terms and Conditions for Self-Archiving." 


\title{
On the Reactivity of Zinc Hydroxide Acetate Dihydrate in Ethanol
}

\author{
Amir Moezzi, ${ }^{[a]}$ Michael B. Cortie, ${ }^{*[a]}$ Ronald Shimmon, ${ }^{[a]}$ and Andrew M. McDonagh ${ }^{[a]}$
}

Keywords: Zinc / Solid state reactions / Basic zinc salts / Zinc hydroxide acetate / Zinc oxide

\begin{abstract}
Zinc hydroxide acetate dihydrate, $\mathrm{Zn}_{5}(\mathrm{OH})_{8}\left(\mathrm{CH}_{3} \mathrm{CO}_{2}\right)_{2} \cdot 2 \mathrm{H}_{2} \mathrm{O}$, reacts in ethanol at room temperature to yield a mixture of zinc oxide and anhydrous zinc acetate. The process is driven by dehydration of the starting salt. Dehydration of $\mathrm{Zn}_{5}(\mathrm{OH})_{8}\left(\mathrm{CH}_{3} \mathrm{CO}_{2}\right)_{2} \cdot 2 \mathrm{H}_{2} \mathrm{O}$ also occurs when it is heated in air, but the product obtained in that case depends sensitively on heating rate, environment and temperature. For example, when it is held in a sealed silica capillary at $100{ }^{\circ} \mathrm{C}, \mathrm{Zn}_{5}(\mathrm{OH})_{8}\left(\mathrm{CH}_{3} \mathrm{CO}_{2}\right)_{2} \cdot 1 \frac{1}{2} \mathrm{H}_{2} \mathrm{O}$ is formed after 15 minutes whereas treatment in the range 90 to $100{ }^{\circ} \mathrm{C}$ in an open environment results in the formation of anhydrous zinc hydroxide acetate. Heating any of these products further causes their decomposition to $\mathrm{Zn}\left(\mathrm{CH}_{3} \mathrm{CO}_{2}\right)_{2}$ and $\mathrm{ZnO}$.
\end{abstract}

\begin{abstract}
The coordination bonding mode of the acetate groups in the anhydrous layered zinc hydroxide acetate prepared by reaction with ethanol was studied using solid-state NMR. The presence of chelating, unidentate and bidentate bridging modes for the carbonyl carbon was revealed but there was no evidence for the inclusion of ethanol in the resultant structure. Therefore the reaction in ethanol offers a convenient strategy to prepare anhydrous zinc hydroxide acetate and/or zinc oxide because it avoids the sensitivity of the thermally-induced dehydroxlation process to time, temperature and environment.
\end{abstract}

\author{
[a] Institute for Nanoscale Technology, University of Technology \\ Sydney, Sydney NSW 2007, Australia \\ E-mail: michael.cortie@uts.edu.au,
}

\begin{abstract}
Supporting information for this article is available on the WWW under http://******* or from the author.
\end{abstract}

\section{Introduction}

Zinc hydroxide acetate dihydrate, $\mathrm{Zn}_{5}(\mathrm{OH})_{8}\left(\mathrm{CH}_{3} \mathrm{CO}_{2}\right)_{2} \cdot 2 \mathrm{H}_{2} \mathrm{O}$, (often reported as zinc hydroxy acetate) is a layered hydroxide salt comprised of sheets of zinc hydroxide cations with intercalated acetate $\left(\mathrm{CH}_{3} \mathrm{CO}_{2}^{-}\right)$groups. ${ }^{[1,2]}$ Several synthetic routes have been reported including aqueous methods, ${ }^{[1,3-6]}$ methods using ammonium hydroxide ${ }^{[7]}$ as well as the formation of $\mathrm{Zn}_{5}(\mathrm{OH})_{8}\left(\mathrm{CH}_{3} \mathrm{CO}_{2}\right)_{2} \cdot n \mathrm{H}_{2} \mathrm{O}$ in alcoholic media. ${ }^{[2,8,9]}$ Inspection of the literature reveals that the reported positions of low angle XRD peaks, which are associated with diffraction from the sheets of this layered compound, vary significantly. In some cases multiple low angle peaks ( $d$-spacings) have been observed. ${ }^{[10]}$ Many of the disparities between the $d$-spacing values can be attributed to the method of synthesis, particularly those using organic solvents such as methanol, ethanol, ethylene glycol and 1,2-propanediol and also methods that use ammonia solutions. Some reports have claimed that the expansion of the interlayer distance is due to the intercalation of more than stoichiometric acetate groups in the gallery spaces. ${ }^{[2]}$ Kasai and Fujihara showed the possibility of intercalation of ethylene glycol to form a hybrid material with a composition of $\mathrm{Zn}_{5}(\mathrm{OH})_{8}\left(\mathrm{CH}_{3} \mathrm{CO}_{2}\right)_{2}\left(\mathrm{HOC}_{2} \mathrm{H}_{4} \mathrm{OH}\right)_{2} \cdot 2 \mathrm{H}_{2} \mathrm{O}$. ${ }^{[9]}$ Nevertheless, in this latter work, the precursor used for the intercalation of ethylene glycol was synthesized in anhydrous methanol. In work by Poul et al., ${ }^{[8]}$ where zinc acetate was dissolved in diethylene glycol, 1,2-propanediol or ethanol, it was noticed that other compositions for the as-synthesized material (reported as $\mathrm{Zn}(\mathrm{OH})_{1.58}\left(\mathrm{CH}_{3} \mathrm{CO}_{2}\right)_{0.42} \cdot 0.31 \mathrm{H}_{2} \mathrm{O}$ based on chemical analysis of $\mathrm{Zn}, \mathrm{C}$ and $\mathrm{H}$ ) might be possible. Interestingly, carbon content was $\sim 13 \%$ higher than expected, which was suggested to arise from physical adsorption of alcohol on the particles. ${ }^{[11]}$ In the work presented here, we show that $\mathrm{Zn}_{5}(\mathrm{OH})_{8}\left(\mathrm{CH}_{3} \mathrm{CO}_{2}\right)_{2} \cdot 2 \mathrm{H}_{2} \mathrm{O}$ reacts in the presence of ethanol to form zinc oxide as well as dehydrated zinc hydroxide acetate, with associated changes in the modes of bonding between the acetate anions and zinc metal centres. Although this process is relatively slow at room temperature, it is an important consideration when synthesizing or using this material in the presence of alcohols that have a dehydrating capacity. However, due to the formation of $\mathrm{ZnO}$, the reaction is not suitable for the purpose of preparing pure dehydrated zinc hydroxide acetate.

\section{Results and Discussion}

Powder XRD data, Figure 1, show that, after suspending $\mathrm{Zn}_{5}(\mathrm{OH})_{8}\left(\mathrm{CH}_{3} \mathrm{CO}_{2}\right)_{2} \cdot 2 \mathrm{H}_{2} \mathrm{O}$ in ethanol for 96 hours, the resultant material contains a significant amount of $\mathrm{ZnO}$. A peak associated with an interlayer distance of $\sim 1.3 \mathrm{~nm}\left(2 \theta=6.0^{\circ}, \mathrm{Cu} \mathrm{K} \alpha\right)$ in the starting material is absent in the data collected for the reacted material while a low intensity peak associated with a $d$-spacing of $\sim 1.75 \mathrm{~nm}$ is present both before and after suspension in ethanol. Previously we showed that $\mathrm{Zn}_{5}(\mathrm{OH})_{8}\left(\mathrm{CH}_{3} \mathrm{CO}_{2}\right)_{2} \cdot 2 \mathrm{H}_{2} \mathrm{O}$ is quite sensitive to dehydration upon heating and that its characteristic XRD peak for $d=1.34 \mathrm{~nm}$ disappears as the material is dehydrated. ${ }^{[6]}$ We hypothesized that ethanol may exert a similar effect, i.e.

$\mathrm{Zn}_{5}(\mathrm{OH})_{8}\left(\mathrm{CH}_{3} \mathrm{CO}_{2}\right)_{2} \cdot 2 \mathrm{H}_{2} \mathrm{O} \stackrel{\text { EtaH }}{\longrightarrow} \mathrm{Zn}_{5}(\mathrm{OH})_{8}\left(\mathrm{CH}_{3} \mathrm{CO}_{2}\right)_{2} \cdot x \mathrm{H}_{2} \mathrm{O}+(2-x) \mathrm{H}_{2} \mathrm{O}$

$\mathrm{Zn}_{5}(\mathrm{OH})_{8}\left(\mathrm{CH}_{3} \mathrm{CO}_{2}\right)_{2} \cdot x \mathrm{H}_{2} \mathrm{O} \rightarrow 4 \mathrm{ZnO}+\mathrm{Zn}\left(\mathrm{CH}_{3} \mathrm{CO}_{2}\right)_{2(\mathrm{~s})}+(4+x) \mathrm{H}_{2} \mathrm{O}$

Decomposition of $\mathrm{Zn}_{5}(\mathrm{OH})_{8}\left(\mathrm{CH}_{3} \mathrm{CO}_{2}\right)_{2} \cdot x \mathrm{H}_{2} \mathrm{O}$ yields $\mathrm{ZnO}$ and zinc acetate $\mathrm{Zn}\left(\mathrm{CH}_{3} \mathrm{CO}_{2}\right)_{2}$, Equation (2). We will show here that $x$ can be $1 \frac{1}{2}$ or zero.

Zinc acetate is reasonably soluble in ethanol $\left(\sim 3 \mathrm{~g} / 100 \mathrm{~mL}^{[12]}\right)$ and by recharging the reaction mixture with fresh ethanol, we were able to drive the decomposition reaction of anhydrous zinc hydroxide acetate to favour the formation of $\mathrm{ZnO}$ at room temperature. 


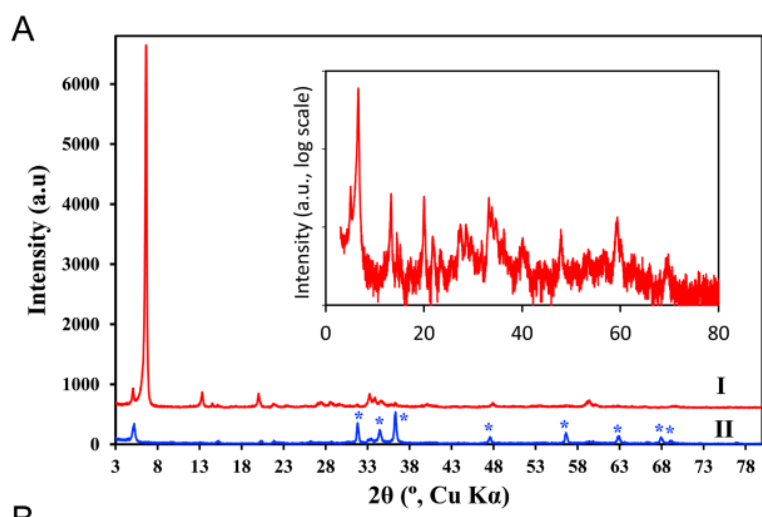

B

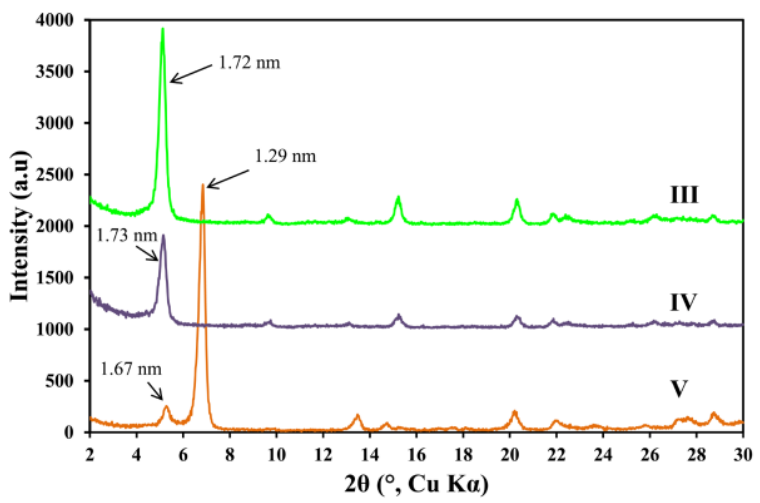

Figure 1. A. Powder $\mathrm{XRD}$ data. (I) $\mathrm{Zn}_{5}(\mathrm{OH})_{8}\left(\mathrm{CH}_{3} \mathrm{CO}_{2}\right)_{2} \cdot 2 \mathrm{H}_{2} \mathrm{O}$ made by method described in ref. ${ }^{[10]}$ showing a characteristic strong peak at $d=1.35$ $\mathrm{nm}$ (also plotted on a logarithmic scale as an inset), and (II) the freeze-dried product obtained after suspending (I) in ethanol for 96 hours. Peaks marked with '*' correspond to ZnO (JC-PDF 01-089-0510. B. (III) Low $2 \theta$ data for II, showing characteristic peak at $\mathrm{d}=1.75 \mathrm{~nm}$., (IV) product of the reaction between $\mathrm{Zn}_{5}(\mathrm{OH})_{8}\left(\mathrm{CH}_{3} \mathrm{CO}_{2}\right)_{2} \cdot 2 \mathrm{H}_{2} \mathrm{O}$ and ethanol dried at $50{ }^{\circ} \mathrm{C}$ under reduced pressure and $(\mathrm{V})$ Low $2 \theta$ data for (I) showing that it also contains a small amount of compound with peak at $\sim 1.7 \mathrm{~nm}$.

Changes in the $\mathrm{X}$-ray diffraction pattern that occur upon heating $\mathrm{Zn}_{5}(\mathrm{OH})_{8}\left(\mathrm{CH}_{3} \mathrm{CO}_{2}\right)_{2} \cdot 2 \mathrm{H}_{2} \mathrm{O}$ at $2{ }^{\circ} \mathrm{Cmin}^{-1}$ in air were investigated for comparison, Figure 2. The $\mathrm{Zn}_{5}(\mathrm{OH})_{8}\left(\mathrm{CH}_{3} \mathrm{CO}_{2}\right)_{2} \cdot 2 \mathrm{H}_{2} \mathrm{O}$ phase (peak at $d=1.34 \mathrm{~nm}$ ) starts to disappear at $89{ }^{\circ} \mathrm{C}$ and is gone by $97{ }^{\circ} \mathrm{C}$, with the X-ray pattern indicating a lowering of the crystallinity of the sample and widening of the interlayer spacing in that temperature range. However, peaks due to $\mathrm{ZnO}$ appear in the pattern only at $\sim 104{ }^{\circ} \mathrm{C}$, and anhydrous zinc acetate only at $115^{\circ} \mathrm{C}$. Clearly, there is an intermediate solid phase between 97 and $104{ }^{\circ} \mathrm{C}$ that was not well crystallised. Therefore, an experiment was carried out whereby the temperature was ramped to $100{ }^{\circ} \mathrm{C}$ at $5{ }^{\circ} \mathrm{Cmin}^{-1}$ and then held at that temperature for 105 minutes while data was collected, Figure 3. In this case the simultaneous formation of the intermediate phase and $\mathrm{ZnO}$ is clearly revealed by the development of a strong peak at $d=1.50 \mathrm{~nm}$ for the former and the strengthening of the characteristics reflections of the latter. We assign this intermediate compound as $\mathrm{Zn}_{5}(\mathrm{OH})_{8}\left(\mathrm{CH}_{3} \mathrm{CO}_{2}\right)_{2} \cdot 1 \frac{1}{2} \mathrm{H}_{2} \mathrm{O}$ (JC-PDF 00-056-0569). ${ }^{[8,10]}$ This in turn decomposed after a further 15 minutes at $100{ }^{\circ} \mathrm{C}$ to form anhydrous zinc acetate and more $\mathrm{ZnO}$.

The formation of the $1 \frac{1}{2} \mathrm{H}_{2} \mathrm{O}$ intermediate phase is reasonably slow and may be skipped if the ramp rate is too high. Surprisingly, the $\mathrm{Zn}_{3}(\mathrm{OH})_{4}\left(\mathrm{CH}_{3} \mathrm{CO}_{2}\right)_{2}$ reported $^{[3,10]}$ to form after prolonged treatments at 90 to $100{ }^{\circ} \mathrm{C}$ (large peak expected at $d=0.95 \mathrm{~nm}, 2 \theta$ $=4.7^{\circ}$ ) is absent in our data collected at $100{ }^{\circ} \mathrm{C}$. This puzzling discrepancy may have arisen because, at $100{ }^{\circ} \mathrm{C}$, the silica capillaries used in our synchrotron experiments retained $\mathrm{H}_{2} \mathrm{O}$ driven from the sample as steam or condensate thereby causing the sample environment to be of high relative humidity. In contrast, free $\mathrm{H}_{2} \mathrm{O}$ would have been rapidly extracted from the solids in the previously reported ${ }^{[3,10]}$ powder diffraction experiments as these samples were open to the atmosphere. The compound with a peak at $\mathrm{d} \approx 1.75 \mathrm{~nm}$ is also missing from the data shown in Figure 2, possibly for the same reason.
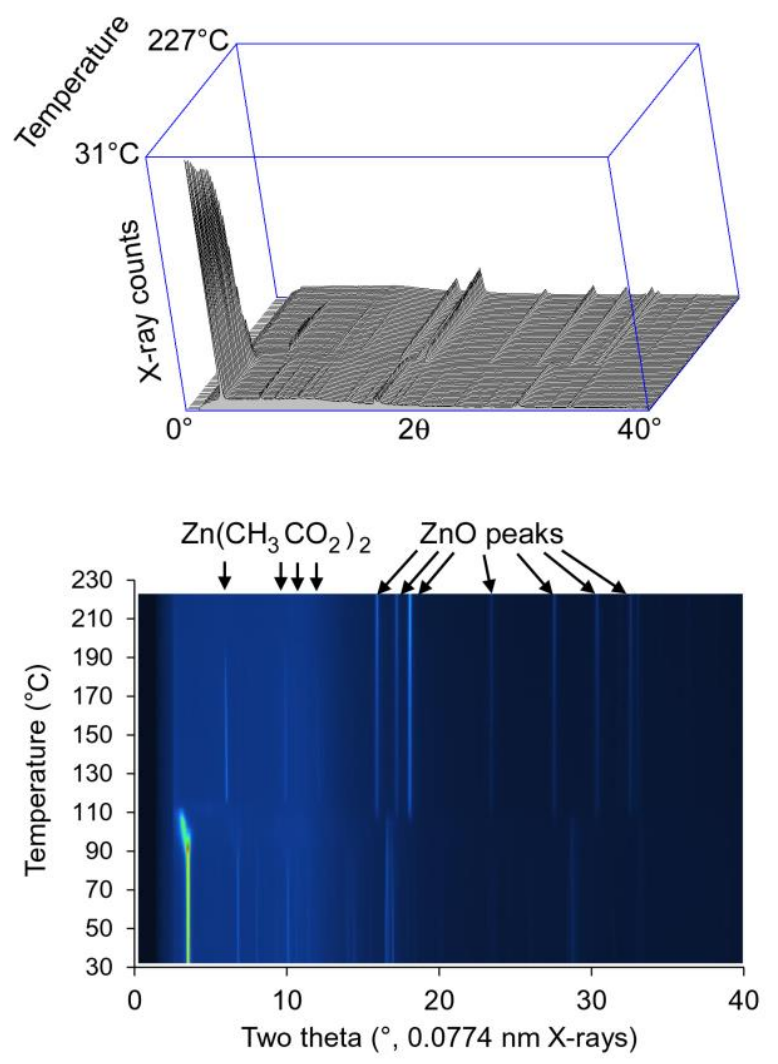

Figure 2. Dehydration of $\mathrm{Zn}_{5}(\mathrm{OH})_{8}\left(\mathrm{CH}_{3} \mathrm{CO}_{2}\right)_{2} \cdot 2 \mathrm{H}_{2} \mathrm{O}$ induced by ramping sample at $2{ }^{\circ} \mathrm{Cmin}^{-1}$ in a synchrotron powder diffraction beamline.

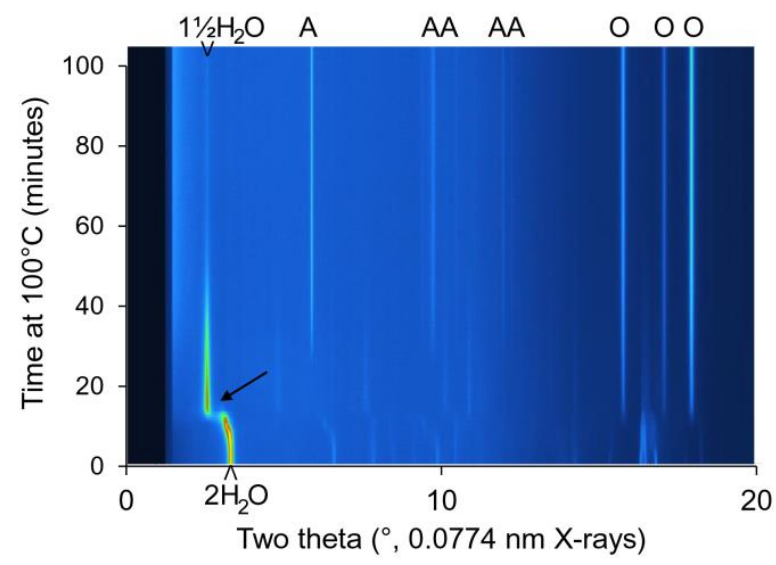

Figure 3. Conversion (arrowed) of $\mathrm{Zn}_{5}(\mathrm{OH})_{8}\left(\mathrm{CH}_{3} \mathrm{CO}_{2}\right)_{2} \cdot 2 \mathrm{H}_{2} \mathrm{O}$ to a mixture of $\mathrm{Zn}_{5}(\mathrm{OH})_{8}\left(\mathrm{CH}_{3} \mathrm{CO}_{2}\right)_{2} \cdot 1 \frac{1}{2} \mathrm{H}_{2} \mathrm{O}$ and $\mathrm{ZnO}$ after $\sim 15$ minutes of isothermal heat treatment at $100{ }^{\circ} \mathrm{C}$. Peaks characteristic of $\mathrm{Zn}\left(\mathrm{CH}_{3} \mathrm{CO}_{2}\right)_{2}$ and $\mathrm{ZnO}$ are marked ' $\mathrm{A}$ ' and ' $\mathrm{O}$ ' respectively.

TGA experiments revealed that the total mass loss value for the product of the reaction of $\mathrm{Zn}_{5}(\mathrm{OH})_{8}\left(\mathrm{CH}_{3} \mathrm{CO}_{2}\right)_{2} \cdot 2 \mathrm{H}_{2} \mathrm{O}$ with ethanol is $20.3 \%$ upon heating to $1000{ }^{\circ} \mathrm{C}$, which is significantly lower than that of $\mathrm{Zn}_{5}(\mathrm{OH})_{8}\left(\mathrm{CH}_{3} \mathrm{CO}_{2}\right)_{2} \cdot 2 \mathrm{H}_{2} \mathrm{O}(37.4 \%)$. There is $\sim 0.9 \%$ mass loss up to $110{ }^{\circ} \mathrm{C}$ but importantly, a dehydration stage is absent (Figure 4). This indicates that immersion in ethanol has removed all of the waters of hydration. The mass loss of $\sim 7.5 \%$ 
between $110-150{ }^{\circ} \mathrm{C}$ is associated with an endothermic process with a peak at $133{ }^{\circ} \mathrm{C}$ (Figure 5) and heating to $\sim 190{ }^{\circ} \mathrm{C}$ results in $\sim 6.6 \%$ mass loss, which is associated with a small and broad endothermic peak at $183{ }^{\circ} \mathrm{C}$. Between $190-400{ }^{\circ} \mathrm{C}$, a further mass loss of $\sim 4.5 \%$ is observed and a broad exotherm is centred at $\sim 197$ ${ }^{\circ} \mathrm{C}$. An overall mass loss of $30 \%$ would be expected if anhydrous $\mathrm{Zn}_{5}(\mathrm{OH})_{8}\left(\mathrm{CH}_{3} \mathrm{CO}_{2}\right)_{2}$ was converted to $\mathrm{ZnO}$. The measured mass loss of $20.3 \%$ is explained considering the XRD data that show that the reaction product already contained a significant amount of $\mathrm{ZnO}$ However, as we showed elsewhere, thermal treatment of $\mathrm{Zn}_{5}(\mathrm{OH})_{8}\left(\mathrm{CH}_{3} \mathrm{CO}_{2}\right)_{2}$ may result in mass loss due to sublimation processes too. ${ }^{[6]}$ It is difficult, therefore, to calculate the exact $\mathrm{ZnO}$ : $\mathrm{Zn}_{5}(\mathrm{OH})_{8}\left(\mathrm{CH}_{3} \mathrm{CO}_{2}\right)_{2}$ ratio in the material produced here from the total mass loss values. Nevertheless, using knowledge about the decomposition mechanism of $\mathrm{Zn}_{5}(\mathrm{OH})_{8}\left(\mathrm{CH}_{3} \mathrm{CO}_{2}\right)_{2} \cdot 2 \mathrm{H}_{2} \mathrm{O}$, ${ }^{[6]}$ a method was developed to estimate the $\mathrm{ZnO}: \mathrm{Zn}_{5}(\mathrm{OH})_{8}\left(\mathrm{CH}_{3} \mathrm{CO}_{2}\right)_{2}$ mass ratio using the mass loss of the first decomposition stage of $\mathrm{Zn}_{5}(\mathrm{OH})_{8}\left(\mathrm{CH}_{3} \mathrm{CO}_{2}\right)_{2}$ that releases four moles of water. This stage occurs prior to the temperatures required for any sublimation processes. The formula below is applied in the temperature range of $110-150{ }^{\circ} \mathrm{C}$ where $X \%$ is the mass fraction of $\mathrm{Zn}_{5}(\mathrm{OH})_{8}\left(\mathrm{CH}_{3} \mathrm{CO}_{2}\right)_{2}$ in the sample.

Observed mass loss $(\%)$ at $110-150^{\circ} \mathrm{C}$

$X \%=100$

Theoretical mass loss (\%) of pure material at $110-150^{\circ} \mathrm{C}$

The theoretical mass loss of pure $\mathrm{Zn}_{5}(\mathrm{OH})_{8}\left(\mathrm{CH}_{3} \mathrm{CO}_{2}\right)_{2}$ for this stage of reaction is $\sim 12.4 \%$. Here, only $7.5 \%$ mass loss was observed in this temperature range. The difference is assigned to the presence of $\mathrm{ZnO}$ in the product. The ratio of observed mass loss value for the product to the theoretical value is calculated to be $60.5 \%$. From these data, the mass ratio of $\mathrm{ZnO}$ : $\mathrm{Zn}_{5}(\mathrm{OH})_{8}\left(\mathrm{CH}_{3} \mathrm{CO}_{2}\right)_{2}$ is calculated to be of the order of $2: 3$.

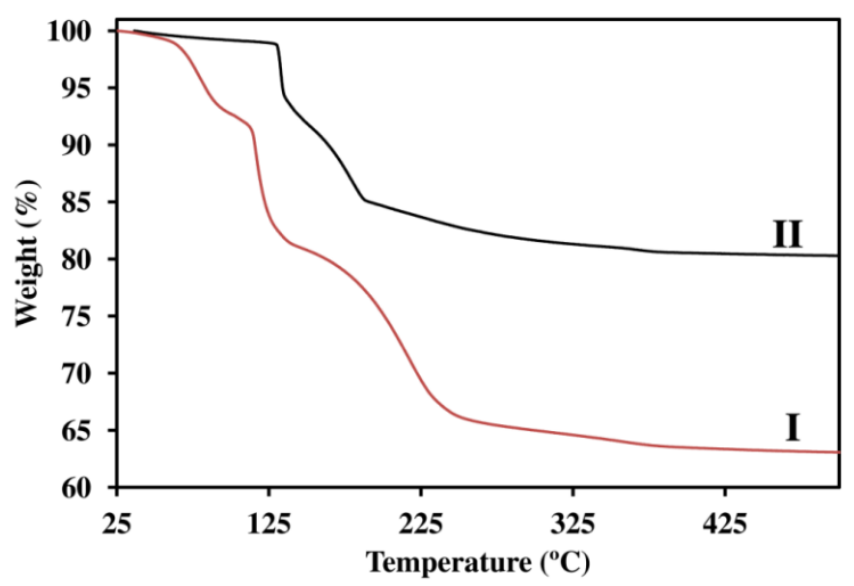

Figure 4. TGA data for (I) $\mathrm{Zn}_{5}(\mathrm{OH})_{8}\left(\mathrm{CH}_{3} \mathrm{CO}_{2}\right)_{2} \cdot 2 \mathrm{H}_{2} \mathrm{O}$, and (II) the freezedried product of the reaction between $\mathrm{Zn}_{5}(\mathrm{OH})_{8}\left(\mathrm{CH}_{3} \mathrm{CO}_{2}\right)_{2} \cdot 2 \mathrm{H}_{2} \mathrm{O}$ and ethanol.

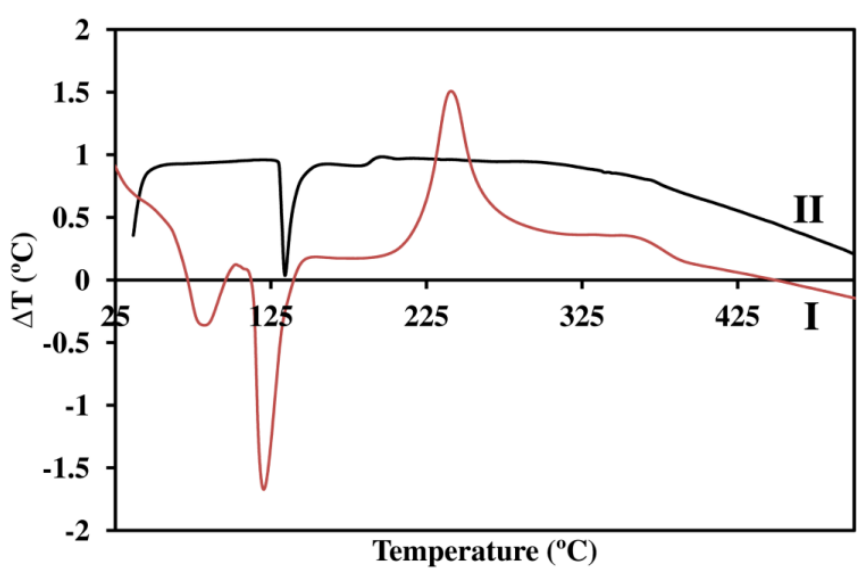

Figure 5. DTA on (I) $\mathrm{Zn}_{5}(\mathrm{OH})_{8}\left(\mathrm{CH}_{3} \mathrm{CO}_{2}\right)_{2} \cdot 2 \mathrm{H}_{2} \mathrm{O}$ and (II) the freeze-dried product of the reaction between $\mathrm{Zn}_{5}(\mathrm{OH})_{8}\left(\mathrm{CH}_{3} \mathrm{CO}_{2}\right)_{2} \cdot 2 \mathrm{H}_{2} \mathrm{O}$ and ethanol. Curve II is available on an expanded vertical axis in the Supporting Information.

The composition of the reaction product was further examined using Raman, FTIR and NMR spectroscopies. Raman spectra of $\mathrm{Zn}_{5}(\mathrm{OH})_{8}\left(\mathrm{CH}_{3} \mathrm{CO}_{2}\right)_{2} \cdot 2 \mathrm{H}_{2} \mathrm{O}$ and the product of its reaction in ethanol are shown in Figure 6. The Raman data are indicative of a material containing $\mathrm{ZnO}$ as well as an acetate-containing compound. Peaks located at $2935 \mathrm{~cm}^{-1}$ are associated with a symmetric $\mathrm{CH}_{3}$ stretch. ${ }^{[13]}$ The peaks centred at $940 \mathrm{~cm}^{-1}$ are associated with $\mathrm{C}-\mathrm{C}$ stretching. ${ }^{[14]}$ A sharp peak located at 438 $\mathrm{cm}^{-1}$ in the spectra of the reaction product corresponds to a nonpolar optical phonon of $\mathrm{ZnO} .^{[15]}$

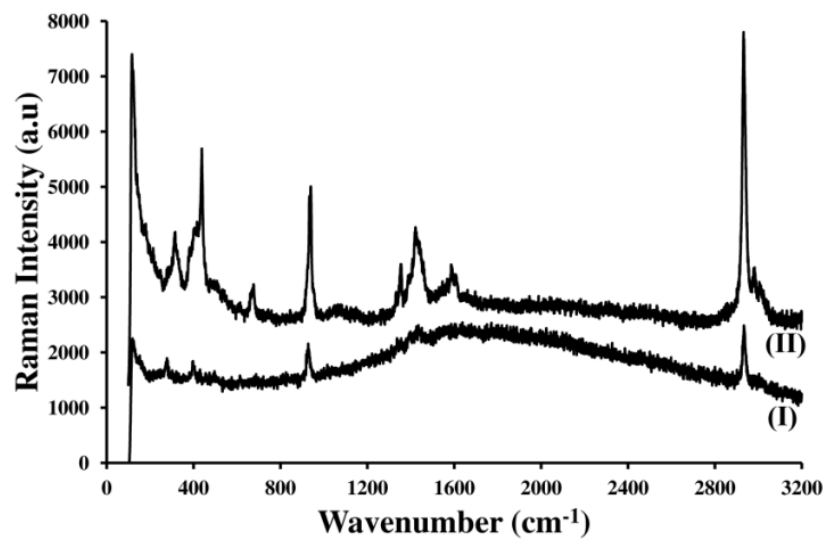

Figure 6. Raman spectra corresponding to (I) $\mathrm{Zn}_{5}(\mathrm{OH})_{8}\left(\mathrm{CH}_{3} \mathrm{CO}_{2}\right)_{2} \cdot 2 \mathrm{H}_{2} \mathrm{O}$ and (II) product of the reaction between $\mathrm{Zn}_{5}(\mathrm{OH})_{8}\left(\mathrm{CH}_{3} \mathrm{CO}_{2}\right)_{2} \cdot 2 \mathrm{H}_{2} \mathrm{O}$ and ethanol, freeze-dried for 24 hours. 

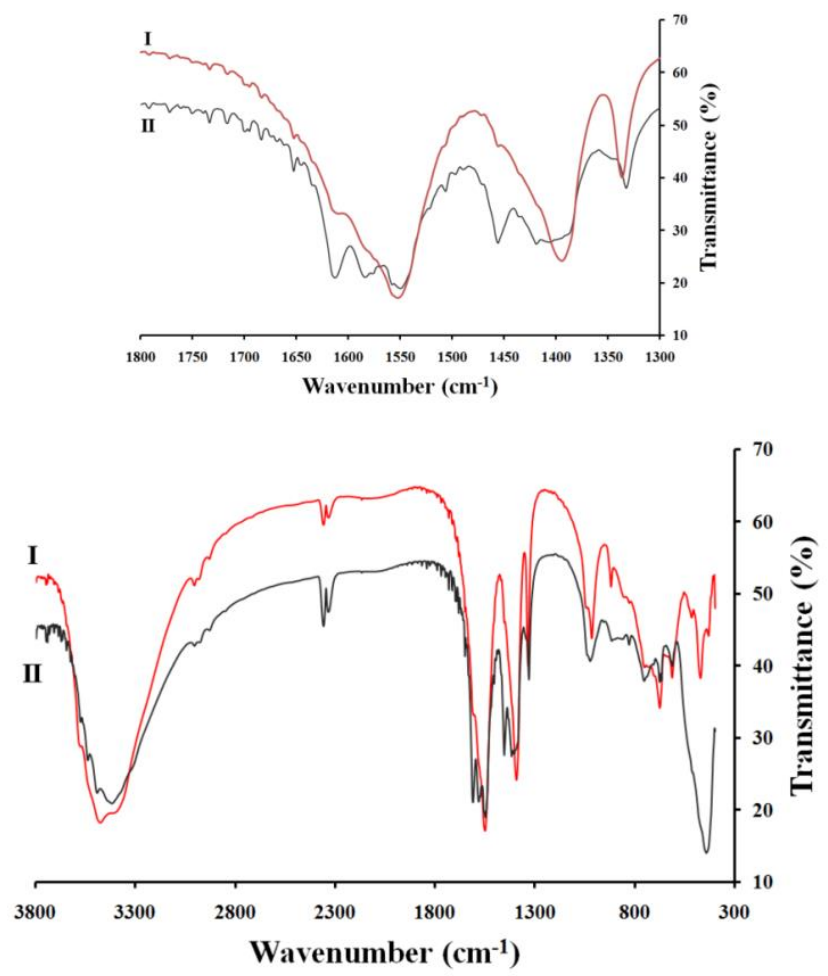

Figure 7. FT-IR spectra corresponding to (I) $\mathrm{Zn}_{5}(\mathrm{OH})_{8}\left(\mathrm{CH}_{3} \mathrm{CO}_{2}\right)_{2} \cdot 2 \mathrm{H}_{2} \mathrm{O}$ and (II) product of the reaction between $\mathrm{Zn}_{5}(\mathrm{OH})_{8}\left(\mathrm{CH}_{3} \mathrm{CO}_{2}\right)_{2} \cdot 2 \mathrm{H}_{2} \mathrm{O}$ and ethanol, freeze-dried for 24 hours. Inset: Expanded view of the region $1800-1300 \mathrm{~cm}^{-1}$.

Table 1.FT-IR spectral assignments for $\mathrm{Zn}_{5}(\mathrm{OH})_{8}\left(\mathrm{CH}_{3} \mathrm{CO}_{2}\right)_{2} \cdot 2 \mathrm{H}_{2} \mathrm{O}$.

\begin{tabular}{lll}
\hline Wavenumbers $\left(\mathrm{cm}^{-1}\right)$ & Assignments & Ref. \\
\hline $3577,3479,3403$ & OH stretching vibrations & {$[13,17]$} \\
$1612 \mathrm{w}, 1583 \mathrm{w}, 1552$ & $\begin{array}{l}\mathrm{COO}^{-} \text {anti-symmetric } \\
\text { stretch }\end{array}$ & \\
& {$[3,13]$} \\
$1456 \mathrm{w}, 1419 \mathrm{w}, 1394$ & $\mathrm{COO}^{-}$symmetric stretch & {$[20]$} \\
1336 & $\mathrm{CH}_{3}$ symmetric bending & {$[20,21]$} \\
$1039 \mathrm{w}, 1016$ & $\mathrm{CH}_{3}$ rocking & {$[20,21]$} \\
\hline
\end{tabular}

Note: "w" denotes weak signal.

Comparing the FT-IR spectrum of $\mathrm{Zn}_{5}(\mathrm{OH})_{8}\left(\mathrm{CH}_{3} \mathrm{CO}_{2}\right)_{2} \cdot 2 \mathrm{H}_{2} \mathrm{O}$ with that of the reaction product reveals significant differences in the regions 430-470 $\mathrm{cm}^{-1}$ and $1300-1700 \mathrm{~cm}^{-1}$ (Figure 7 and Table 1). A peak centred at $437 \mathrm{~cm}^{-1}$ is assigned to a $\mathrm{Zn}-\mathrm{O}$ stretching vibration ${ }^{[15]}$ while peaks at 1614,1583 and $1550 \mathrm{~cm}^{-1}$ are assigned to a $\mathrm{COO}^{-}$anti-symmetric stretch and peaks at 1456, 1419 and 1400 $\mathrm{cm}^{-1}$ are assigned to the $\mathrm{COO}^{-}$symmetric stretch. The separation between the $\mathrm{COO}^{-}$anti-symmetric and symmetric stretches $\left(\Delta v_{\mathrm{a}-\mathrm{s}}=\right.$ $\left.v_{\mathrm{a}}\left(\mathrm{COO}^{-}\right)-v_{\mathrm{s}}\left(\mathrm{COO}^{-}\right)\right)$have been reported to yield information about the bonding mode of the acetate anion to the zinc metal centre. ${ }^{[16]}$ Types of carboxylate bonding to divalent metal cations can be expressed as $\Delta v_{\mathrm{a}-\mathrm{s}}$ (unidentate) $>\Delta v_{\mathrm{a}-\mathrm{s}}$ (ionic) $\geq \Delta v_{\mathrm{a}-\mathrm{s}}$ (bridging bidentate) $>\Delta v_{\mathrm{a}-\mathrm{s}}$ (chelating). ${ }^{[16]}$ For $\mathrm{Zn}_{5}(\mathrm{OH})_{8}\left(\mathrm{CH}_{3} \mathrm{CO}_{2}\right)_{2} \cdot 2 \mathrm{H}_{2} \mathrm{O}$, there is a difference of 1552-1394 = $158 \mathrm{~cm}^{-1}$. This value is less than the $164 \mathrm{~cm}^{-1}$ reported for sodium acetate, which exhibits ionic bonding and thus might suggest a bridging bidentate or chelating coordination mode. ${ }^{[16]}$ For the reaction product, we have found separations of 164,158 and 150 $\mathrm{cm}^{-1}$. The $164 \mathrm{~cm}^{-1}$ separation is identical to that reported for sodium acetate ${ }^{[17,18]}$ and suggests that ionic carboxylate bonding might be involved. ${ }^{[16]}$ A value of $150 \mathrm{~cm}^{-1}$ suggests that a chelating mode exists in the structure. ${ }^{[16]}$ Therefore, the material appears to have at least three types of carboxylate bonding. However, resolving this issue based only upon FT-IR data is problematic ${ }^{[16]}$ and so solid-state $\mathrm{NMR}^{[19]}$ experiments were conducted.

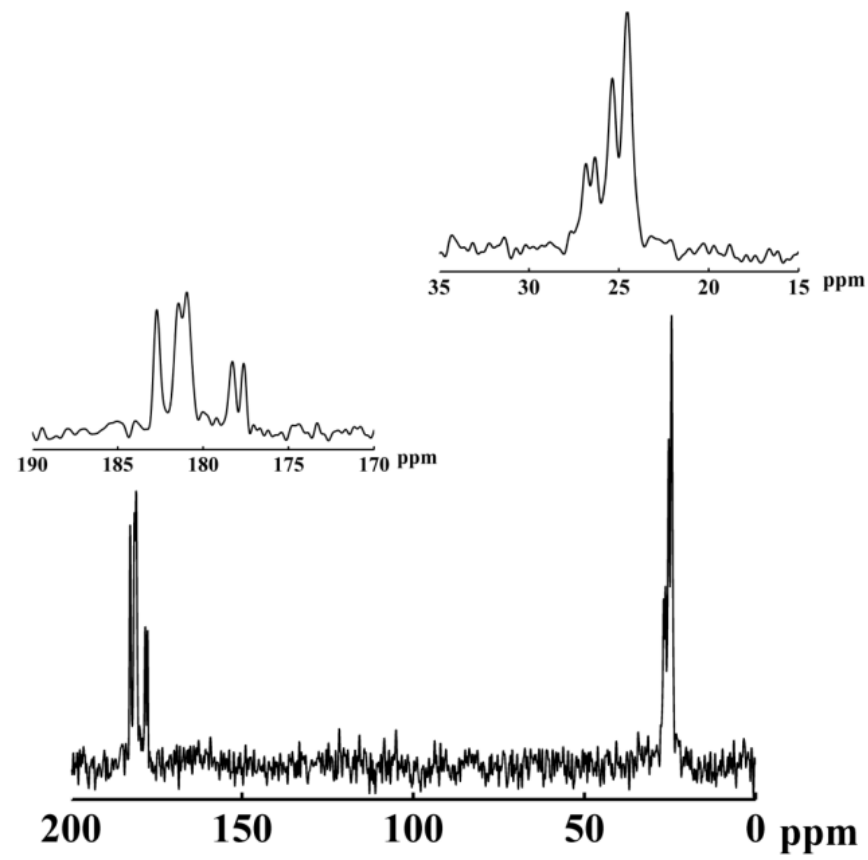

Figure 8. CP-MAS ${ }^{13} \mathrm{C}$ NMR spectrum of the product of the reaction between $\mathrm{Zn}_{5}(\mathrm{OH})_{8}\left(\mathrm{CH}_{3} \mathrm{CO}_{2}\right)_{2} \cdot 2 \mathrm{H}_{2} \mathrm{O}$ and ethanol, freeze-dried for 24 hours.

The ${ }^{13} \mathrm{C}$ CP-MAS NMR spectrum of the product of the reaction between $\mathrm{Zn}_{5}(\mathrm{OH})_{8}\left(\mathrm{CH}_{3} \mathrm{CO}_{2}\right)_{2} \cdot 2 \mathrm{H}_{2} \mathrm{O}$ and ethanol is shown in Figure 8. In contrast to the spectrum of $\mathrm{Zn}_{5}(\mathrm{OH})_{8}\left(\mathrm{CH}_{3} \mathrm{CO}_{2}\right)_{2} \cdot 2 \mathrm{H}_{2} \mathrm{O}$ that contains only two major peaks located at $\sim 180$ and $25 \mathrm{ppm},{ }^{[6]}$ the spectrum of the product of the reaction between $\mathrm{Zn}_{5}(\mathrm{OH})_{8}\left(\mathrm{CH}_{3} \mathrm{CO}_{2}\right)_{2} \cdot 2 \mathrm{H}_{2} \mathrm{O}$ and ethanol shows several signals in each region. Nevertheless the locations of the signals are in the same region associated with methyl (0-45 ppm) and carbonyl (160$190 \mathrm{ppm})$ groups. ${ }^{[22]}$ No signal corresponding to ethoxy carbon environments in the range of $60-110 \mathrm{ppm}^{[22]}$ was detected indicating that ethanol has not been incorporated in the reaction product structure. Five signals assigned to resonances of the carbonyl carbon were detected at $\delta: 177.6,178.3,181,181.5$ and 182.7. Also four signals assigned to resonances of the carbon atom associated with $\mathrm{CH}_{3}$ were detected at $\delta: 24.5,25.4,26.3$ and 26.8 ppm. A signal at $182.7 \mathrm{ppm}$ suggests the presence of chelating coordination mode for the carbonyl group whereas a resonance at $177.6 \mathrm{ppm}$ suggests a unidentate mode. ${ }^{[19]}$ The intermediate signals show bidentate bridging state or a combination of modes. This finding confirms the presence of acetate in the material but with different types of coordination modes compared to $\mathrm{Zn}_{5}(\mathrm{OH})_{8}\left(\mathrm{CH}_{3} \mathrm{CO}_{2}\right)_{2} \cdot 2 \mathrm{H}_{2} \mathrm{O}$.

\section{Conclusions}

In summary, we have shown that zinc hydroxide acetate dihydrate in ethanol at room temperature undergoes dehydration to form zinc oxide. Comparison with thermally treated zinc hydroxide acetate dihydrate indicates that anhydrous zinc hydroxide acetate, $\mathrm{Zn}_{5}(\mathrm{OH})_{8}\left(\mathrm{CH}_{3} \mathrm{CO}_{2}\right)_{2}$ readily forms $\mathrm{ZnO}$ and zinc acetate. By removing the reasonably soluble zinc acetate in ethanol, we were able to drive the reaction towards the production of $\mathrm{ZnO}$. The anhydrous zinc hydroxide acetate compound remaining after 96 hours in ethanol exhibits more than one bonding mode between the 
acetate anions and the zinc metal centres, but there is no evidence of coordinated or intercalated ethanol. The reaction of zinc hydroxide acetate in ethanol is of practical interest because it provides a convenient way to prepare anhydrous zinc hydroxide acetate and/or nanocrystalline $\mathrm{ZnO}$, and because it has implications for instances where zinc hydroxide acetate dihydrate is synthesized or used in alcoholic media.

\section{Experimental Section}

Zinc hydroxide acetate dihydrate, $\mathrm{Zn}_{5}(\mathrm{OH})_{8}\left(\mathrm{CH}_{3} \mathrm{CO}_{2}\right)_{2} \cdot 2 \mathrm{H}_{2} \mathrm{O}$, ${ }^{[6]}$ was stirred in ethanol for a period of 96 hours with fresh ethanol introduced at 24 hour intervals (see Supporting Information). The freeze-dried product (close to $100 \%$ yield) was characterised by powder X-ray diffraction (XRD), thermogravimetric analysis (TGA) and differential thermal analysis (DTA), Raman and infra-red spectroscopy, and ${ }^{13} \mathrm{C}$ nuclear magnetic spectroscopy (NMR). In situ X-ray diffraction experiments at various temperatures were conducted on the Powder Diffraction Beamline at the Australian Synchrotron with samples held in spinning $0.3 \mathrm{~mm}$ diameter silica capillary tubes (see Supporting Information for experimental details).

Supporting Information (see footnote on the first page of this article): Method of preparation for $\mathrm{Zn}_{5}(\mathrm{OH})_{8}\left(\mathrm{CH}_{3} \mathrm{CO}_{2}\right)_{2} \cdot 2 \mathrm{H}_{2} \mathrm{O}$ and description of other experimental techniques used.

\section{Acknowledgments}

This work was supported by PT. Indo Lysaght (Indonesia). We also thank Dr. K. Kannangara from School of Science and Health, UWS, Australia for solid-state NMR. The in situ XRD was undertaken on the Powder Diffraction beamline at the Australian Synchrotron, Victoria, Australia.

[1] H. Morioka, H. Tagaya, M. Karasu, J. Kadokawa, K. Chiba, J. Mater. Res., 1998, 13, 848-851.

[2] E. Hosono, S. Fujihara, T. Kimura, H. Imai, Journal of Colloid and Interface Science, 2004, 272, 391-398.

[3] T. Biswick, W. Jones, A. Pacula, E. Serwicka, J. Podobinski, Solid State Sciences, 2009, 11, 330-335.

[4] E. Kandare, J. M. Hossenlopp, Inorganic Chemistry, 2006, 45 , 3766-3773

[5] A. Kawai, Y. Sugahara, I. Y. Park, K. Kuroda, C. Kato, in Ceramic Transactions, Ceramic Powder Science IV, eds. S Hirano, G. L. Messing and H. Hausner, American Ceramic Society, 1991, pp. 75-80.

[6] A. Moezzi, A. McDonagh, A. Dowd, M. Cortie, Inorganic Chemistry, 2013, 52, 95-102.
[7] Q. Cui, K. Yu, N. Zhang, Z. Zhu, Applied Surface Science, 2008 254, 3517-3521.

[8] L. Poul, N. Jouini, F. Fievet, Chemistry of Materials, 2000, 12, 3123-3132.

[9] A. Kasai, S. Fujihara, Inorganic Chemistry, 2006, 45, 415-418.

[10] A. Moezzi, A. M. McDonagh, A. Dowd, M. B. Cortie, Inorganic Chemistry, 2013, 52, 95-102.

[11] M. Taibi, S. Ammar, N. Jouini, F. Fie'vet, Journal of Physics and Chemistry of Solids, 2006, 67, 932-937.

[12] J. A. Dean, Lange's Handbook of Chemistry, McGraw Hill, Inc. New York, 1999.

[13] J. Hedberg, S. Baldelli, C. Leygraf, Journal of the Electrochemical Society, 2010, 157, C363-C373.

[14] J. Hedberg, S. Baldelli, C. Leygraf, E. Tyrode, Journal of the Electrochemical Society, 2010, 157, C357-C362.

[15] A. J. Reddy, M. K. Kokila, H. Nagabhushana, J. L. Rao, C Shivakumara, B. M. Nagabhushana, R. P. S. Chakradhar, Spectrochimica Acta Part A: Molecular and Biomolecular Spectroscopy, 2011, 81, 53-58.

[16] G. B. Deacon, R. J. Phillips, Coordination Chemistry Reviews, 1980, 33, 227-250

[17] U. Kumar, J. Thomas, N. Thirupathi, Inorganic Chemistry, 2010, 49, 62-72.

[18] H. Noma, Y. Miwa, I. Yokoyama, K. Machida, Journal of Molecular Structure, 1991, 242, 207-219.

[19] B.-H. Ye, X.-Y. Li, I. D. Williams, X.-M. Chen, Inorganic Chemistry, 2002, 41, 6426-6431.

[20] R. Q. Song, A. W. Xu, B. Deng, Q. Li, G. Y. Chen, Adv. Funct. Mater., 2007, 17, 296-306.

[21] T. Ishioka, Y. Shibata, M. Takahashi, I. Kanesaka, Y. Kitagawa, K. T. Nakamura, Spectrochimica Acta Part A: Molecular and Biomolecular Spectroscopy, 1998, 54, 1827-1835.

[22] A. De Marco, R. Spaccini, P. Vittozzi, F. Esposito, B. Berg, A Virzo De Santo, Soil Biology and Biochemistry, 2012, 51, 1-15.

Received: ((will be filled in by the editorial staff)) Published online: ((will be filled in by the editorial staff) 


\section{Entry for the Table of Contents}

\section{Layout 2:}

(Zinc Hydroxide Acetate)

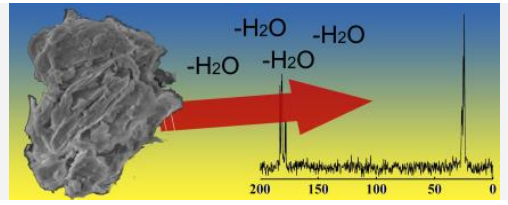

Decomposition of zinc hydroxide acetate dihydrate in ethanol can be exploited to generate $\mathrm{ZnO}$ nanoparticles at room temperature. The mechanism involves the removal of waters of hydration and the formation of $\mathrm{Zn}_{5}(\mathrm{OH})_{8}\left(\mathrm{CH}_{3} \mathrm{CO}_{2}\right)_{2}$ followed by the generation of $\mathrm{Zn}\left(\mathrm{CH}_{3} \mathrm{CO}\right)_{2}$ and $\mathrm{ZnO}$.
Amir Moezzi, Michael B. Cortie,* Ronald Shimmon, and Andrew $M$. McDonagh Page No. - Page No.

On the Reactivity of Zinc Hydroxide Acetate Dihydrate in Ethanol

Keywords: Zinc / Solid state reactions / Basic zinc salts / Zinc hydroxide acetate / Zinc oxide 